\title{
Young Beninese People's Views Regarding Colonization: A Preliminary Study
}

\section{Perspectivas de jóvenes benineses respecto a la colonización: Un estudio piloto}

Received: 26 August 2017 | Accepted: 01 December 2018

\author{
ORnheIlia ZounON ${ }^{\mathrm{a}}$ \\ University of Abomey-Calavi, Benín \\ Etienne Mullet \\ Institute of Advanced Studies, Francia
}

ORCID: http://orcid.org/0000-0002-1707-3914

a Corresponding author. E-mail: ornheilia@yahoo.fr

How to cite: Zounon, O., \& Mullet, E. (2019). Young Beninese people's views regarding colonization: A preliminary study. Universitas Psychologica, 18(4), 1-8. https://doi.org/10.11144/Javeriana.upsy18-4.ybpv

\begin{abstract}
The present study explored and mapped young Beninese people's views regarding colonization. A sample of 63 students aged 18-20 and living in Cotonou, Benin were presented with 24 cards showing a story that depicted a colonization process and asked to assess each process using a response scale that ranged from "very negatively" to "rather positively". Each story had four critical items of information: (a) the political/ economic situation before colonization (e.g., the area was virtually stateless), (b) the colonial policy of the metropolis (e.g., pure exploitation of the colony's riches and the building of a minimal infrastructure needed for easing exploitation), (c) the extent to which the average people's standard of living and life expectancy increased during the colonial period, and (d) the level of brutality with which the colonizer's rule was applied. Three qualitatively different positions were found: Always very negatively (4\%), Undecidable (20\%), and Depends on circumstances (74\%). This majority position was that, even if colonization deprived African people of their right to self-determination, the colonizer's action must be assessed taking into account the pros and the cons in each concrete situation. In other words, colonization was, in the case of Africa, not good or bad in itself. This view is in some way not that dissimilar from the one western Europeans may have today regarding past colonization by the Romans. Keywords

colonization; Benin; personal positions.
\end{abstract}

\section{RESUMEN}

Este estudio piloto intentó cartografiar las perspectivas de los jóvenes benineses hacia la colonización. Una muestra reducida de 63 participantes de entre 18 y 20 años, examinó 24 escenarios de la descripción de un proceso de colonización, y expresó su opinión hacia cada proceso, utilizando una escala continua cuyos dos extremos fueron muy negativo y muy positivo. Los procesos estaban descritos en función de cuatro factores: (a) la situación política y económica antes de la colonización, (b) la política colonial de la metrópolis, (c) si la situación de bienestar de la población había crecido o no durante el periodo de colonización y (d) el grado de violencia con el cual la política de la metrópolis fue aplicada. Tres posiciones cualitativamente distintas fueron encontradas: (a) muy negativo en todos los casos (4\%), no se puede decir (20\%) y depende de 
lo que ocurrió en concreto (76 \%). La posición de la mayoría de los jóvenes fue entonces de considerar que, aunque la colonización haya privado los habitantes de parte de sus derechos (p. ej., la autodeterminación), la acción de los colonizadores tiene que ser evaluada en función de los aspectos positivos y de los aspectos negativos en cada situación. En otros términos, la colonización no fue en sí misma considerada como mala o como buena. Esta forma de ver no es, en un cierto modo, bastante similar a la visión que los europeos del oeste pueden tener ahora de la colonización romana de veinte siglos atrás.

Palabras clave

colonización; Benín; posiciones personales.

The present study was aimed at exploring and mapping young Beninese people's views regarding colonization: To what extent and under which circumstances can the balance sheet of a particular colonization process be considered as globally positive or negative? Colonization is the process by which a group of people or a country - usually but not necessarily a powerful group or country - sends people outside its usual borders either to definitely settle there and cultivate the land (hence the original meaning of the term "colony"), or to first assess and then exploit the riches that can be found in these places (Young, 2015). This process describes, of course, the original spread of humanity from its "native" place in Africa to the whole earth. Since the early in history, some examples of colonization have been particularly well documented. For example, Greek and Roman historians described how, in antiquity, Greek cities colonized many places around the Mediterranean (Cicero, 1995). Some of these places have become and are still today prosperous cities (e.g., Empuria Brava, Marseilles, and Sevastopol).

When the areas where colonizers decide to settle are virgin--that is, when nobody has lived there before--colonization does not pose any moral problem. When these places have already been settled by other people, however, moral problems inevitably arise because colonizers are apt to violate each of the four principles of good conduct in human affairs: Respect for autonomy, justice, non-maleficence, and beneficence. Firstly, colonization implies that the respect for people's autonomy principle of good conduct in human affairs is baffled. Powerful colonizers usually deny to less powerful local populations any right to self-determination Firstly, colonizers ignore autonomy by usually denying less powerful local populations any right to self-determination.: native people are expected to align with colonizers' views and plans. As a recent and striking example, more than one million African males living in European colonies were recruited during the First World War, sometimes forcibly (Osuntokun, 1977), and sent to the battle front in Eastern France where a majority of them were killed or severely injured.

Secondly, colonizers often deliberately violate the principle of justice when, in order to facilitate governance, they ally with and favor one social class or ethnic minority in order to gain control over the whole country. In order to ease governance, colonizers use to seek support from one social class in the colony or from one ethnic minority in the population to gain control over the whole colony (Strauss, 2006). Also, in order to ease exploitation of the country's riches, colonizers often deny to colonized people any right to them.

Thirdly, colonizers disregard the principle of non-maleficence when, for example, they use violent means to overcome natives' resistance to colonization (e.g., forced work, forced displacement, killings and full scale battles) (de las Casas, 1552/1992; Ki-Zerbo, 1978; Sautter, 1967). During colonization processes, smallpox, measles, whooping cough, tuberculosis, and influenza killed large fractions of defenseless people. In at least in some cases, colonizers did nothing to prevent the spread of infection (Chrisjohn, Young, \& Maraun, 2006; Milloy, 1999).

Fourthly, colonizers seldom apply the principle of beneficence since they usually have in mind the economic and political interests of their own group or country, not those of the colonized people. Immemorial economic ties with neighboring groups are often severed, and all economic exchanges are redirected to the colonizing country. This durably destabilizes 
the local productive system and, as a result, accentuates poverty and underfeeding and can favor epidemics (Acemoglu, Johnson, \& Robinson, 2001).

Promoters of colonization in the 19th century and current day defenders of colonization have tended to deny that any of these principles of good conduct in human affairs are or have been violated. They have argued that at the time of colonization, the colonized people, being from inferior races, were not autonomous people (Fanon, 2004; Stoler, 1989), were often totally unable to govern themselves, and were continuously at war with their neighbors (Osterhammel, 1997). Through colonization, they contend, the colonized people have gained more autonomy; that is, they have learned how to govern themselves and how to make peace with neighbors.

Promoters and defenders of colonization have also argued that it was beneficial, not detrimental, to the colonized people. They point to the building of useful infrastructure (e.g., railways); the creation of heath centers and hospitals; the sharing of scientific knowledge and technological skills through the creation of primary, secondary, and technical schools; and the spread of the true faith through the action of missionaries (Lugan, 2003). The increase of population in Africa from $1880(120,000,000$ inhabitants) to 1975 (400,000,000 inhabitants) (Adu Boahen, 2000) has been interpreted as a definite proof that colonization of Africa during part of the $20^{\text {th }}$ century was, overall, beneficent.

Assessing colonization processes is inevitably a complex issue on which even prominent intellectuals' opinions diverge (Sorum, 1977). Regarding colonization of the whole earth by Homo sapiens, it would be difficult for any of us to conclude that this process was bad overall (but see Lovelock, 2009). Regarding colonization of Western Europe by the Romans, it would also be difficult for current-day British, French or Spanish people to conclude that this process was without any positive benefits for the colonized, even if the Roman administration may, in their ancestors' views, have appeared at this time as fundamentally predatory.
Regarding the colonization in Africa during the last two centuries, the picture is much less clear. Authors vary greatly in their assessment of the benefits of colonization for the colonized people. Some argue that the colonization of Africa has been completely detrimental to the Africans (e.g., Rodney, 2011). Others argue that, overall, its impact has been positive (e.g., Austin, 2010; Fergusson, 2004; Gann \& Duignan, 1967; von Albertini, Wirz, \& Williamson, 1982). Still other suggest that, at least from an economical perspective, this kind of question has no answer owing to the complete intertwining of metropolitan and colonial economies (Aron, 1959). Finally, some authors argue that it is the colonizing countries that have suffered the detriments for colonizing countries (Clark, 1936; Marseille, 1984). As early as 1811, Adam Smith suggested that granting independence to their colonies would, on average, benefit the British economically. It is, however, interesting to observe that most newly independent African nations chose to retain privileged economic ties to their former colonizers (e.g. the Commonwealth of Nations).

\section{The Present Study}

As stated above, the present study was aimed at exploring and mapping young Beninese people's views regarding colonization. It was an exploratory study; that is, we wished to know whether gathering and analyzing the views of young people who currently live in a former French colony - Benin -. was feasible. As in many studies of this kind (Armange \& Mullet, 2016; Kpanake \& Mullet, 2011, Mukashema \& Mullet, 2015; Mullet et al., 2016), the current study used realistic scenarios. In this study the scenarios depicted the situation of a country that has just been granted independence. Four factors were manipulated in these scenarios.

The first factor was the political/economic situation before colonization. Heldring and Robinson (2012) suggested that the impact of colonization partly depended on the political organization found by colonizers. In areas that 
were stateless (e.g., Somalia) and very poor, colonization may have had a positive impact overall. In areas that already had structured institutions and an efficient production system, colonization may have had a much less positive impact.

The second factor was the colonial policy of the metropolis. Investment in colonies during the $19^{\text {th }}$ and $20^{\text {th }}$ centuries varied greatly as a function of the colonizing country. For example, the Portuguese were above all interested in exploiting the riches available in Angola or Mozambique. They built minimal infrastructures and left it up to churches and missionaries to do most colonial activities. By contrast, the British built huge infrastructures that still exist today (e.g., the Cape to Uganda railway) and schooled many young people in order to create a reservoir of well-trained employees that could mediate British rule in the area or more efficiently manage local companies (Cogneau, 2003).

The third factor was the extent to which average people's standard of living and life expectancy increased during the colonial period. Finally, the fourth factor was the level of brutality with which the colonizer's rule was applied. In some part of Africa (e.g., Belgian Congo), colonizers instituted such a reign of terror that other colonial countries had no other choice than to protest publicly at a time when brutality towards reticent locals was seen everywhere as the norm.

Participants were presented with the different scenarios and asked to judge the extent to which the colonizer's action -- the colonization process -- depicted in each case should be assessed as positive or negative. Our hypothesis was that at least three qualitatively different positions would be found and that these positions would resemble positions that have been found among experts.

The first position would be called Always very negatively. This position has been advocated by authors such as Rodney (2011) for whom, even if colonization was well intended, brutality was kept at a minimum, and colonized people's standard of living has improved, colonization was evil because it deprived African people of power (the principle of respect for autonomy).
Participants holding this position would rate all scenarios using the negative side of the response scale. The second position would be called Undecidable, as advocated by Aron (1959, see above). Participants holding this position would rate all scenarios in the same way, using only the medium area of the response scale.

The third position would be called Depends on Circumstances. Participants holding this position would use the entire range of the response scale and rate scenarios as a function of the information that is given. This pragmatic position is similar in spirit to empirical analyses published by authors such as Ferguson (2004), Fieldhouse (1999), Huillery (2009), and Warren (1980). For example, Huillery (2009, 2011) reported a positive relationship between an area's current level of performance - in terms of functionality of infrastructures, public health, and level of school attendance - and the extent of previous colonial investments. This author also reported a relationship between current patterns of public spending (e.g., in education) and former patterns of colonial investments, with measurable consequences on the availability of public goods today.

\section{Method}

\section{Participants}

Participants were 63 students (49\% females) aged 18-20 and living in Cotonou, Benin. They were contacted in the university campus and in high schools. The study conformed to the ethical recommendations of the Beninese and French Societies of Psychology; that is, full anonymity was respected and informed consent was obtained from all participants.

\section{Material}

The material consisted of 24 cards showing a story of a few lines and a response scale. Each story had four critical items of information in the following order: (a) the political/economic 
situation before colonization (the area was virtually stateless and people lived in very poor conditions, with a reduced life expectancy vs. the area was organized in small kingdoms, there was no famine and people's life expectancy was quite high), (b) the colonial policy of the metropolis (pure exploitation of the colony's riches and the building of a minimal infrastructure needed for easing exploitation, or the building of a huge infrastructure necessary for the economic development of the area as well as hospitals and the creation of towns, or the building of a huge infrastructure in association with considerable investment in public education (primary schools, high schools, and universities), (c) the extent to which the average people's standard of living and life expectancy increased during the colonial period (small increases vs. considerable increases), (d) the level of brutality with which the colonizer's rule was applied (not much brutality vs. brutality as the rule). The 24 scenarios were obtained by orthogonally crossing the four factors. The resulting design was Previous Situation x Colonizer's Policy x Level of Life x Brutality, $2 \times 3 \times 2 \times 2$ ).

An example of a scenario was the following: "The republic of Malevia colonized part of Africa 150 years ago. In this part of Africa there was no political organization; the area was virtually stateless. The standard of living was very low, mortality was high, and people's life expectancy was about 32. Famines were frequent owing to climatic fluctuations and limited agrarian techniques and equipment. Malevia did more than just exploit the agricultural, forestry, and mineral riches of their colony. They built much of the infrastructure needed for the economic development of the colony (roads, railways, bridges, warehouses, rural health centers, and hospitals). They were also concerned with education. Many schools were built. Many young people in the colony attended primary schools and some of them benefited from secondary and tertiary education. Others received professional training. Christian missions also operated in the whole area. The treatment of local farmers was, by contrast, especially brutal. The farmers who, from the colonizers' viewpoint, did not work enough have been severely punished and at times killed for the example. The standard of living of the population increased considerably during the colonial period owing to better food, technological equipment, and progress in hygiene. Average life expectancy has reached 53 years. Last year, this colony gained independence. How do you assess the colonizer's actions?" Participants rated each scenario using an elevenpoint scale $(0-10)$ ranging from very negatively on the left to rather positively on the right.

\section{Procedure}

Each participant was tested individually at school or at the university. They were told that the names of the colonizing country were fictitious but that they might recognize situations that may have existed somewhere in Africa. The procedure followed Anderson's (2016) recommendations for this kind of study. The experimenter instructed the participants that, for each scenario, they had to indicate the degree to which they feel that the colonizer's action can be considered as very negative or rather positive. She also explained to them how to use the response scale and did this in such a way that their opinions would not be influenced; that is, she never mentioned her own position regarding the colonizer's policy in concrete cases. Participants took 30 to 40 minutes to complete the ratings.

\section{Results}

Each ratings pattern was visually inspected (Schlottman, 2001). In two cases (about 4\% of the sample), all ratings were low and the mean rating (for the two participants) was 0.43 . These participants were grouped together into a cluster that was called Always very negatively. In 13 cases (about 20\% of the sample), all ratings were close to the middle of the response scale low and the mean rating was 5.12 . These participants were also grouped together into a cluster that was called Undecidable. 
In the remaining 48 cases $(76 \%)$, mean ratings ranged from 2.83 to 8.33 . As a result, these participants were grouped into a cluster that was called Depends on Circumstances. This cluster is shown in Figure 1. An ANOVA was conducted on the raw data using the design indicated above (see Table 1). Owing to the great number of comparisons performed, the significance threshold was set at .001 . Ratings were higher (a) when the increase in colonized people's standard of living was high $(M=6.78)$ than when it was low $(M=4.53), F(1,47)=$ $75.37, \eta_{\mathrm{p}}^{2}=.62$, (b) when brutalities were kept at a minimum $(M=6.38)$ than when they were the rule $(M=4.94), F(1,47)=32.29, \eta_{p}^{2}=.41$, (c) when the policy included the building of infrastructure and the schooling of young people $(M=6.22)$ than when it included only the building of infrastructure $(M=5.73)$ or was only aimed at exploitation $(M=5.03), F(2,94)=$ $19.08, \eta_{p}^{2}=.29$, and (d) when the colonized area was stateless and poor $(M=5.93)$ than when it was already politically organized $(M=5.39), F(1$, 47) $=12.58, \eta_{\mathrm{p}}^{2}=.21$.

\section{Figure 1}

The Depends on Circumstances Position.

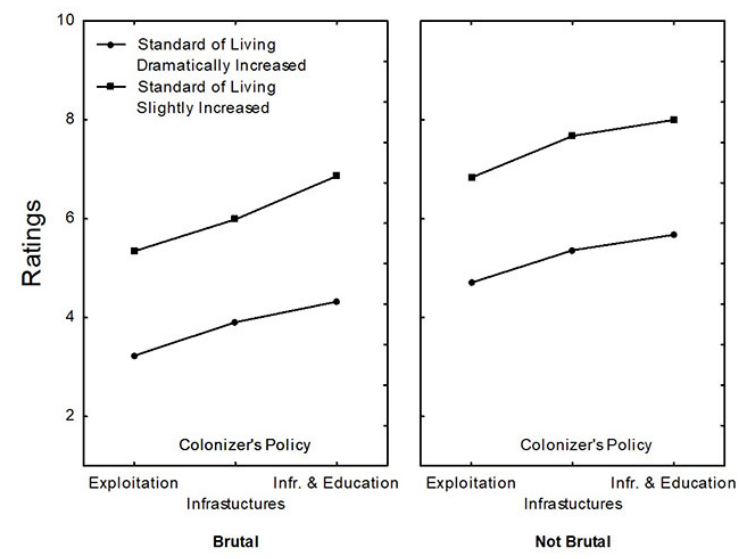

\section{Discussion}

The three expected positions were found. The majority position was that, even if colonization deprived African people of their right to selfdetermination, the colonizer's action must be assessed taking into account the pros and the cons in each concrete situation. For a majority of participants, colonization was, in the case of Africa, not good or bad in itself. It depended on the way it was implemented and on its consequences for the colonized people. In some way, this view is not that dissimilar from the one western Europeans may have today regarding past colonization by the Romans. Historians have shown that the Romanization of Western Europe had high human costs and have insisted that the Roman administration channelled most production surplus to the imperial capital. Nonetheless, most people today in Spain, France or England would be unwilling to denounce Roman colonization as evil or to assess its impact as totally negative.

Of the four factors that were manipulated in the scenarios, two had a stronger impact that the others: the increase in standard of life and the level of brutality. These two factors synthesise the consequences of colonization in terms of economic benefits and human cost. Information about the colonizer's policy and the politico-social situation before colonization was taken into account, but its effect was viewed by participants as largely mediated by the information conveyed by the other factors. Also, these two factors are, owing to the current situation, the ones to which people in general must be the most sensitive: the standard of living in western African countries is still low and fluctuating, and eruptions of violence are always to be feared.

The Always very negatively position was present but was extremely rare. This contrasts with its apparent current-day popularity in the media and in political discourse; it has been current practice in Western Europe and in Africa at large to denounce colonization as evil. Also, the Undecidable position was found. Twenty percent of participants expressed their incapacity at assessing the quality of the colonizer's action. It is unlikely that more than a few would have shared Aron's (1959) arguments regarding decidability, but the fact is that rather than considering all colonization processes as evil, they preferred to express indecision. 


\section{Limitations}

As stated early, the present study was preliminary. The small sample size and its restriction to young students prevent any generalization of findings to people at large in Benin. These results are, however, intriguing enough to report. Using scenarios to capture and map Beninese people's positions regarding colonization is feasible, at least among people with a certain level of education. Most participants do not limit themselves either to stating that the colonizers' action was always negative and destructive or to expressing their incapacity to assess it, which was one of our major concerns before launching the study. They are ready to agree with the idea that, in some cases, the colonizer's action was very negative, as when brutality was extreme and local people received no benefit, whereas in other cases, it may have been positive, as when brutality was minimal and there were clear material, health, and educational benefits. The young generation may be able to free themselves from a fixation on the colonial past and from leaders who identify with this past, to unite with their peers in constructing a new country, and to work constructively on this task with the former colonial powers or any other partner country.

\section{References}

Acemoglu, D., Johnson, S., Robinson, J. A. (2001). The colonial origins of comparative development: An empirical investigation. The American Economic Review, 91(5), 1369-1401. Retrieved from https://www.jst or.org/stable/2677930?seq $=1$

Adu Boahen, A. (Ed.). (2000). General history of Africa: Africa under colonial domination 1880-1935. Berkeley: University of California Press.

Albertini, R., von, Wirz, A., \& Williamson, J. G. (1982). European colonial rule, 1880-1914: The impact of the west on India, South East Asia and Africa. Westport: Greenwood Place.
Anderson, N. H. (2016). Information integration theory: Unified Psychology based on three mathematical laws. Universitas Psychologica, 15(3), 1-7. https://doi.org/10.11144/Javeria na.upsy15-3.iitu

Armange, R., \& Mullet, E. (2016). Slave descendants' views regarding national policies on reparations: A Martinican perspective. Social Science Information, 55, 511-530. https://doi.org/10.1177/05390184 16658150

Aron, R. (1959). Les conséquences économiques de l'évolution politique en Afrique noire. Revue Française de Science Politique, 3,\# 610-628. Retrieved from https://www.persee.fr/doc/rfsp_00352950_1959_num_9_3_403016

Austin, G. (2010). African economic development and colonial legacies. International Development Policy, 1, 11-32. h ttps://doi.org/10.4000/poldev.78

Casas, de las B. (1992). The devastation of the Indies: A brief account. Baltimore: John Hopkins University Press.

Chrisjohn, R., Young, S., \& Maraun, M. (2006). The circle game: Shadows and substance in the Indian residential school experience in Canada. Penticton, BC: Theytus Books.

Clark, G. (1936). The balance sheets of imperialism: Facts and figures on colonies. New York: Columbia University Press.

Cogneau, D. (2003). Colonization, school and development in Africa. An empirical analysis. Paris: Institut de Recherche pour le Développement.

Fanon, F. (2004). The wretched of the earth. New York: Grove Press.

Ferguson, N. (2004). Empire: How Britain made the modern world. London: Penguin.

Fieldhouse, D. K. (1999). The West and the Third World: Trade, colonialism, dependence and development. Hoboken: Wiley.

Gann, L. H., \& Duignan, P. (1967). Burden of empire: A appraisal of western colonialism south of the Sahara. Stanford: Hoover Institution Press.

Heldring, L., \& Robinson, J. A. (2012). Colonialism and economic development in 
Africa (Working Paper N. ${ }^{\circ}$ 18566). Cambridge, MA: National Bureau of Economic Research. Retrieved from https:/ /ideas.repec.org/p/nbr/nberwo/18566.html

Huillery, E. (2009). History matters: The longterm impact of colonial public investments in French West Africa. American Economic Journal: Applied Economics, 1, 176-215. htt ps://doi.org/10.1257/app.1.2.176

Huillery, E. (2011). The impact of European settlement within French West Africa: Did pre-colonial prosperous areas fall behind? Journal of African Economies, 20, 263-311. h ttps://doi.org/10.1093/jae/ejq030

Ki-Zerbo, J. (1978). Histoire de l'Afrique Noire. Paris: Hatier.

Kpanake, L., \& Mullet, E. (2011). Judging the acceptability of amnesties. Conflict Resolution Quarterly, 28(3), 291-313. https: //doi.org/10.1002/crq.20024

Lovelock, J. (2009). The vanishing face of Gaia. New York: Basic Books.

Lugan, B. (2003). God bless Africa: Contre la mort programmée du continent noir. Rennes: Carnot.

Marseille, J. (1984). Empire colonial et capitalisme français. Histoire d'un divorce. Paris: Albin Michel.

Milloy, J. S. (1999). A national crime: The Canadian government and the residential school system, 1879-1986. Winnipeg: University of Manitoba Press.

Mukashema, I., \& Mullet, E. (2015). Attribution of guilt to offspring of perpetrators of the genocide: Rwandan people's perspectives. Conflict Resolution Quarterly, 33, 75-98. htt ps://doi.org/10.1002/crq.21128

Mullet, E., López López, W., Kpanake, L., Mukashema, I., Armange, R., Kamble, S., ... Neto, F. (2016). Functional measurement in the field of ethics in politics [Special issue]. Universitas Psychologica, 15(3), 1-26. https://doi.org/10.11144/Javeri ana.upsy15-3.fmf

Osterhammel, J. (1997). Colonialism: A theoretical overview. Princeton, NJ: M. Wiener.
Osuntokun, J. (1977). West African armed revolts during the First World War. Tarikh, 5(3), 6-17.

Rodney, W. (2011). How Europe underdeveloped Africa. Baltimore: Black Classic Press.

Sautter, G. (1967). Notes sur la construction du chemin de fer Congo-Océan (1921-1934). Cahiers d'Etudes Africaines, 26, 219-299. Retrieved from https://www.persee.fr/doc/c ea_0008-0055_1967_num_7_26_3098

Schlottmann, A. (2001). Children's probability intuitions: Understanding the expected value of complex gambles. Child Development, 72, 103-122. https://doi.org/1 0.1111/1467-8624.00268

Smith, A. (1811). The nature and causes of the wealth of nations. London: Cadell.

Sorum, P. C. (1977). Intellectuals and decolonization in France. Chapel Hill: University of North Carolina Press.

Stoler, A. L. (1989). Making empire respectable: The politics of race and sexual morality in 20th-century colonial cultures. American Ethnologist, 16, 634-660. Retrieved from ht tp://www.jstor.org/stable/645114

Strauss, S. (2006). The order of genocide: Race, power, and war in Rwanda. Ithaca: Cornell University Press.

Warren, B. (1980). Imperialism, pioneer of capitalism. London: Verso.

Young, R. J. C. (2015). Empire, colony, postcolony. Oxford: Wiley-Blackwell.

\section{Notes}

* Research article. 